\title{
Dynamics of Salinity and Land Use in Punjab Province of Pakistan
}

\author{
Arshad Mahmood Malik ${ }^{1 *}$, Hafiz Muhammad Tayyab ${ }^{1}$, Muhammad Arshad Ullah ${ }^{2}$ and Muhammad Talha \\ Bilal $^{3}$
}

${ }^{1}$ Pir Mehr Ali Shah Arid Agriculture University, Rawalpindi, Pakistan; ${ }^{2}$ Pakistan Agricultural Research Council, Pakistan; ${ }^{3}$ COMSATS University Pakistan.

Abstract | Agricultural economy of Pakistan is vital for provision of food and employment for 207.77 million populations. This economy is mainly threatened by salinity which is expanding to $6.28 \mathrm{mha}$, thus developing wasteland of $2 \mathrm{~m}$ ha due to presence of highsalinity. The injudicious use of brackish underground water is one of the major factorsresponsible for increased salinity ultimately effecting productivity in Pakistan. Salinity hasdevastating socio- economic impact on farmer's micro economy in Pakistan, directly impactingliving standard, migration, health, the crumbling of houses, and harming tocommunication and transport. The study in hand was designed to investigate the impact of salinity on irrigated area, uncultivated area and wheat area in Punjab using panel data of four agriculture census conducted in1980, 1990, 2000 and 2010 in all districts of Punjab. Fixed and random effect model was applied on panel data of Punjab. The area left uncultivated by farmer due to presence of salinity was found to be significantly and positively related to area under salinity in the country. The percent area under wheat crop has inverse relationship with salinity indicating strength of wheat cultivation against salinity. It is therefore three prong strategy is recommended with different roles and responsibility on the part of Farming community, public sector and research institutions. Results of the study have important implications for planners and policy makers in developing projects to mitigate salinity in the country.

Received | May 11, 2019; Accepted | November 20, 2020; Published | January 31, 2021

*Correspondence | Arshad Malik, Pir Mehr Ali Shah Arid Agriculture University, Rawalpindi, Pakistan; Email: arshadmm@uaar.edu.pk

Citation | Malik, A., H. Tayyab, A. Ullah and M. Talha.2021. Dynamics of salinity and land use in Punjab Province of Pakistan. Pakistan Journal of Agricultural Research, 34(1): 16-22.

DOI | http://dx.doi.org/10.17582/journal.pjar/2021/34.1.16.22

Keywords | Salinity, Wheat yield, Irrigated area, Uncultivated area, Punjab

\section{Introduction}

$\mathrm{T}$ he agricultural sector support Pakistan's economy in provision of food for the 211.17 million people (GOP, 2020) and increasing with the pace of 2.10 percent per annum (World Bank, 2015). Over $800 \mathrm{~m}$. ha. of land around the globe is salt-affected either saline or sodic soils or both), associating to over six percent of the land area of the globe (FAO, 2010). Furthermore, around $15 \mathrm{~m}$. ha. of land faces yield reduction due to soil affected in less develop countries (Tilman et al., 2002). High salinity of soil is major environmental issue limiting thedevelopment of agriculture in coastal areas (Hillel, 2000; Yadav et al., 2011). Pakistan has atotal area of 79.6 millionhectare (mha), with 22.05 mha. cultivated land (GOP, 2020) and $6.28 \mathrm{mha}$ affected by salt (GOP, 2012). Salinity has serious socioeconomic repercussions on agricultural communities of the country, which leads to affect living standard, rural urban migration, serious health issues, the collapsing of houses, and disturbing communications and transportation (Hollington, 2001). Selection and breeding for improved tolerance against salinity in different cropsis considered as high priority due to its economic benefits and best alternative. The other strategies to mitigate salinity are costly and unaffordable for the farming community (Ashraf, 2009). 
Tolerance against salinity in two major cereal crops and stable food (wheat and rice) is considered as an important tool to mitigate world hunger and ensure food security among masses (FAO, 2010). Salinity applies adverse effect on wheat with a seriousdecrease in productivity (Aldesuquy and Ibrahim, 2002). Wheat may be produced efficiently with saline water irrigation if farmers adopt recommended salinity mitigation practices for its cultivation (Ghane et al., 2011). Lesser supplyof fresh water and gradual increasein the need for inspiringpractices creating motivating to stakeholder to apply marginal quality water in agriculture (Mojid et al., 2012). Irrigation by saline water has advantage of decrease the demand of fresh water for salt-tolerantcrops (Bath et al., 2017). Butsoil salinity has its repercussions at critical stages of growth of crops and ultimately reduces crop productivity. This leads to management of saline water irrigation in suitableway for the specific crop.

Salts present in the soil water decreases evapotranspiration which leads to poor availability of water for crop, its exchange in the root zone (Heidarpour et al., 2009) soil structure disturbance and decreases biodiversity and human health problems (Williams, 2001; Sheikhzeinoddin et al., 2016; Shannon and Grieve, 1998). Salinity is a collective problem for Pakistan, as well as for developing and developed countries.

As per Food and Agriculture Organisation Land and Plant Nutrition Management Service, salinity or sodicity has affected above six percent of land in the world. Furthermore, the poor water quality as brackishwater is the major cause of plant stress. The intensity of stress is severe in areas of having high evaporation rate main in arid and semi-arid regions having fragmented saline soils whichincreases salinity and decreases land yield around the world (Atlassi et al., 2009). Secondary salinization is also considered to be the major cause of salinity in Pakistan (Inam et al., 2017).

The United Nations Environment Program estimated that around half of world cropland indicates stress due to salt (Yokoi et al., 2002). Irrigated lands are mostly affected by salt stress which is accounted for twenty percent of crop and in some countries like Egypt, Argentina and Iran, this figure approaches to thirty percent (Zink, 2003). Salinity also affects different parts of plant like in wheat phonological characteristics like leaf number, leafrate expansion, root/shoot ratio, and total dry matter yield (E1Hendawy et al., 2005). Salinity adversely effects farm income (Inam, 2017) and price differential also exists among cultivated and uncultivated aquifers (Foster, 2018). Rising water table is affecting agriculture productivity due to increase in salinity (Khan et al., 2016). Salinity adaptation strategies have positive externalities for improving crop production and farmer's income (Mustafa and Akhtar, 2019). Thus salinity is affecting land use and farmer's income and ultimately to national economy. To investigate this factor in Punjab, this study was designed to explore the impact of salinity on land use pattern in diverse districts of Punjab.

\section{Materials and Methods}

Punjab province of Pakistan has diverse climate ranging from mountains to plains, irrigated delta and deserts. District wise data of salinity in Punjab (Figure 1) was obtained from Agriculture Census of 1980, 1990, 2000 and 2010 (GOP, 1981, 1991, 2001, 2011) on the basis of 1980 classification with little modification to avoid the duplications of Islamabad capital territory (ICT) and Hafizabad. As per 1980 census, data of 17 districts were available. Further ICT and Hafizabad districts were added. In later census, the data of new districts created was merged to maintain harmony in data. Irrigated area, uncultivated area and percentage area under wheat were taken as variables to highlight their impact on salinity and vice versa.



Figure 1: Map of Punjab province on the basis of EC (Source: Directorate of Soil Fertility Research Institute Punjab).

\section{Model formulation and data analysis}

Area under salinity was mainly caused due to over irrigation and leaving area uncultivated due to salinity and low productivity. Over $86 \%$ of the wheat crop is irrigated in Pakistan and covered almost $90 \%$ of Rabi 
area and provide $45 \%$ of the daily calorie intake to the population. Punjab province provides $70 \%$ of wheat to the country (USDA, 2011). Area under wheat represents the dominant cropping pattern of the area.

Fixed and Random effect model was used for analysis of panel data of all districts of Punjab (Pakistan). Stata software was applied for drawing inferential and descriptive statistical analysis of the data. In the Stata, regression was run first with fixed effect, then with random effect to differentiate among fixed and random effect with Hausman test as this test perform well for penal data (Mutl and Pfaffermayr, 2011). The probability value of $\mathrm{chi}^{2}$ statistics $\chi^{2}=0.2155$ was greater than 0.05 , therefore random effect model was applied in this study.

\section{Statistical model}

Area under salinity in Punjab is the function of area under irrigation by farmer's uncultivated area and area under wheat.

Area under salinity $=\mathrm{f}$ (Irrigated area, Uncultivated area, Wheat area)

For the estimation purpose above equation can be rewritten as follows;

$$
\mathrm{Sa}=\beta_{0}+\beta_{1} \mathrm{X}_{1}+\beta_{2} \mathrm{X}_{2}+\beta_{3} \mathrm{X}_{3}+\mu_{\mathrm{t}}
$$

\section{Where;}

$\mathrm{Sa}$ is area under salinity; $\beta$ 's are coefficients of $\mathrm{X} ; \mathrm{X}_{1}$ is irrigated area; $\mathrm{X}_{2}$ is uncultivated area; $\mathrm{X}_{3}$ is wheat area.

This represents the Population Regression Function (PRF) for estimation of effect of three variables on the dependent variable which is linear in nature. PRF describes the change of conditional means due to change in $\mathrm{x}$ (Das, 2019). For the estimation purpose, it can be transformed into Multiple Regression Function (Gujarati and Porter, 2003).

$\mu \mathrm{t}$ is the error term or disturbance term in the model and indicate random variable with well defined probabilistic characteristics. The residual term $\mu \mathrm{t}$ different factors affecting dependent variable which are not considered explicitly.

Classical linear regression model (CLRM) is used as basis of the model with set of assumptions of least square estimators. The model is based on the assumption of good fit; if assumptions of CLRM are fulfilled. In case of violation of these assumptions, the results will be misleading (Zeng, 2019). Violation of these assumptions may be called limitation of the model. On the basis of these assumptions, the results are considered to be good fit if model has no autocorrelation, no heteroscedasticity, no multicollinearity and normally data.

\section{Results and Discussion}

The results of the study revealed that irrigation with brackish water had positive impact on salinity in all districts of Punjab. The intensity of salinity in Punjab increased due to use of brackish water as $47 \%$ of the underground water is marginally fit for irrigation (Chopra and Krishan, 2014). Results indicated thatone-unitincrease in irrigation with brackish water has increased salinity by 0.01 unit (Table 1). Concentration of salts in water (Salinity) is generally measured by electrical conductivity (EC) and application of low quality irrigation water in the cultivated land (Acosta et al., 2011). The underground water contains sufficient amount of salts which causes increase in salinity in the area (Acosta et al., 2011; Sagin et al., 2017). The variable is non-significant as $p$ value of $t$ stat is greater than 0.05 and positive signs indicates direct relationship with salinity (Atlassiet al., 2009). This can be controlled with manure and drainage management in Pakistan (Valipour, 2014).

Wheat is a staple food of Pakistan and hasinverse relationship with salinity. Results indicated that increase inone-unit wheat production on saline soil, decreased the salinity upto 0.018 units (Table 1 ). The $\mathrm{p}$ value of wheat area is greater than 0.05 indicating non-significant relationship and these results are consistent with (Aldesuquy and Ibrahim, 2002; Ghane et al., 2011). The reason might be the leaching down effect of salts through cultivation of wheat on saline soils.

Uncultivated area in saline districts of Punjab has positiveand significant impact on salinity. When uncultivated area increased, salinity increased (Geo et al., 2015). When farmers leave the cultivated area without cultivation due to low productivity, it becomes more vulnerable to salinity. Results indicated that salinitywas increased by 0.12 units due to a unit increase in uncultivated area (Table 1). P value of variable is less than 0.01 indicatingsignificant effect of the variables 
$(\mathrm{P}<0.01)$. Results follow economic theory as many global studies reported same results (FAO, 2010).

The more the area remains under cultivation, the lower the probability of salinity. Results indicated that more the area farmer cultivate under wheat (being major staple food and covering $90 \%$ of area in Rabi), the lower the probability of salinity. But area under wheat crop has non-significant effect on salinity as results of the model indicated $(\mathrm{P}>0.1)$ (Table 1$)$.

\section{Table 1: Effect of salinity on land use of Punjab.}

$\begin{array}{llll}\text { Salinity } & \text { Code } & \text { Coefficients } & \text { Probability } \\ \text { Irrigated area } & \text { (ia) } & +0.0143 & 0.105 \\ \text { Uncultivated area } & \text { (ua) } & +0.1239 & 0.000 \\ \text { Wheat percentage } & \text { (sw) } & -0.0182 & 0.188 \\ \text {-cons } & & 2343.97 & 0.587\end{array}$

Different factors affecting salinity in Punjab districts was analyzed in Figure 2. This figure shows thesalinity status in different districts of Punjab in relation to irrigated area, uncultivated area and area under wheat, which are independent variables of the model. The uncultivated area of Muzaffargar his high while salinity is also second highest in the province. The irrigated area of Multan is very highand salinity is also highest in the province (Figure 2). The Central Punjab is highly polluted followed by Southeast Punjab as reported by Khan and Khan, 2020. The results indicated that salinity and area under wheat has inverse relationship. By focusing in these districts, wheat production was increased while salinity trend wasdecreased with the decrease of salinity in these districts according to Agri, Census of Punjab, 1980, (GOP, 1981).

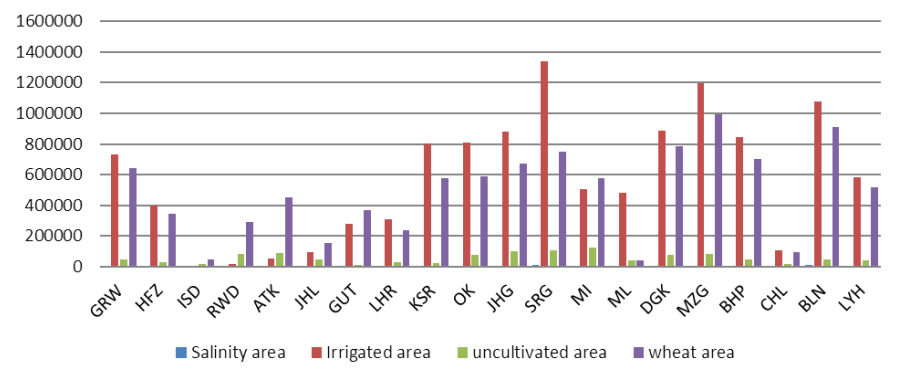

Figure 2: Distribution of salinity in relation to uncultivated, irrigated and wheat area in 1980.

District wise analysis among salinity and independent variables revealed the salinity status of different districts in Punjab during 1990 (Figure 3). The uncultivated area of Muzaffargarh is very high in
1990 (Figure 3) and corresponding yield of wheat is also high. It was found that wheat area was increased as salinity level decreased in Punjab during 1990.

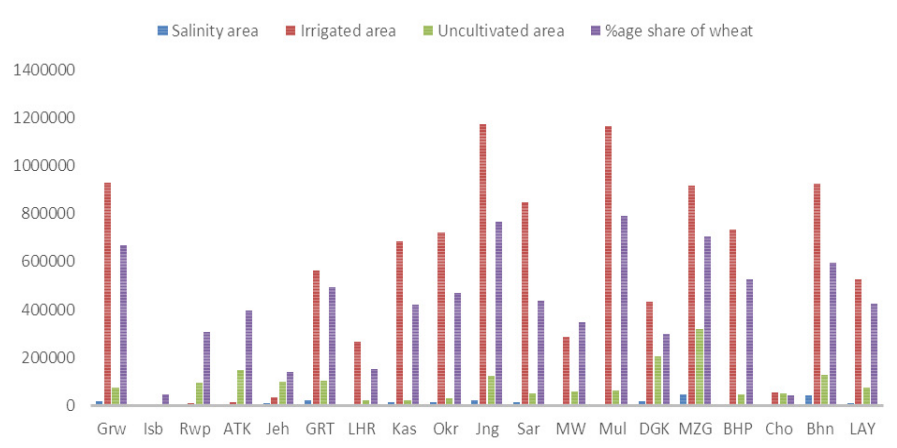

Figure 3: District wise distribution of salinity in relation to uncultivated area, irrigated area and wheat share during 1990.

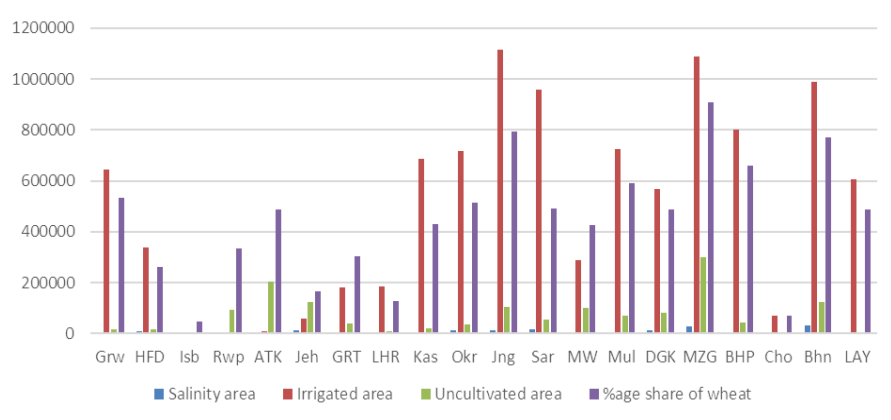

Figure 4: District wise distribution of salinity in relation to uncultivated area, irrigated areaand wheat share during 2000.

The comparison of the variables was made in cross sectional way. The uncultivated area of Muzaffargarh was high (Figure 4) as compared to others probably due to more deserts in the area. The area under wheat was also high in Muzaffargarh. Reduction in the salinity decreased uncultivated areain Punjab during 2000.

The irrigated area of Sargodha was high along with the wheat area. Reduction in salt-affected area was indicated showing enhancement inwheat produce in the province of Punjab in 2010 (Figure 5). The uncultivated area of the province of Punjab greatly reduced as well as salinity in 2010 .

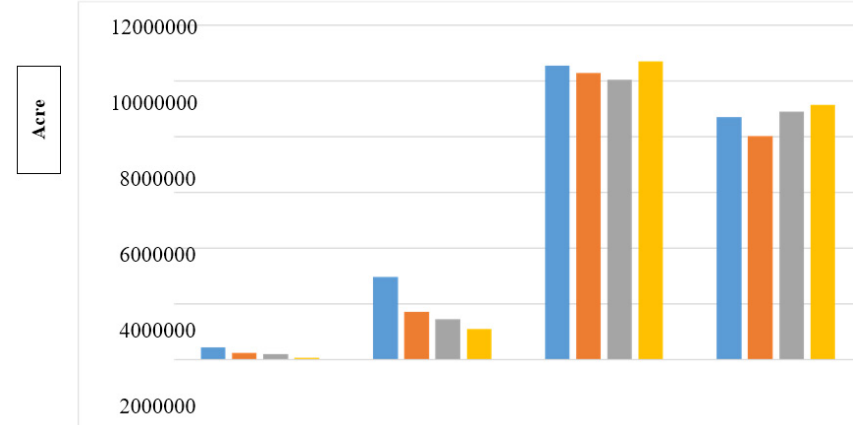

Figure 5: District wise distribution of salinity in relation to uncultivated area, irrigated areaand wheat share during 2010. 
The uncultivated area has direct and significant relationship with salinity in Punjab.It was revealed that the salinity in Punjab drops down as uncultivated area decreased during last four decades (Figure 6). Salinity and irrigated areas had also direct but non-significant relationship from 1980 to 2010 and this increase in salinization due to irrigation causes reduction in fruit yield (Rodrigues et al, 2018). Salinity was increased when land was irrigated with poor quality water. In Punjab, 0.588 million tube wellswere installedannually in 2003 and in 2018number of tube wells increased by 1.1 million (Bureau of Statistics Punjab, 2020). The intensive extraction of underground water through tube wells causes salinization in Punjab (Hussain et al., 2017).

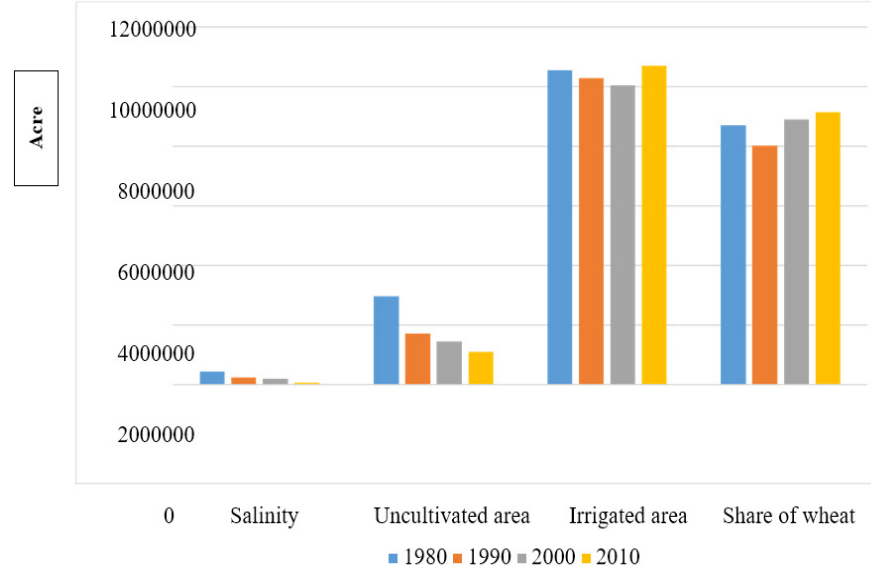

Figure 6: Comparison of factors affecting soil salinity during 19802010.

\section{Conclusions and Recommendations}

The panel data study was conducted using secondary data of all districts of Punjab to analysis the effect of irrigated area, uncultivated area and area under wheat on salinity in Punjab province of Pakistan using random effect model. Results indicated that salinity is significantly influenced by mainly uncultivated area while other variables have non-significant effect on salinity. Uncultivated area has positive effect on salinity.

A three prong strategy is recommended for controlling salinity in Punjab based on finding of this study. First, farmer should keep cultivating area especially under wheat crop to control salinity in the country even if how severe the salinity is. Second, Government should use legislation/incentive for continuous cultivation of lands facing salinity issues. Third, research institutes should focus on developing salt tolerance wheat varieties as a measure to control salinity in the country.

\section{Novelty Statement}

Although many studies explored the secondary data on the salinity profile, none have assessed the district wise profile of secondary information (penal data) in special reference to spatial variation in land use patternslike irrigated area, uncultivated area and wheat sowing by applyingFixed and random effect model. Leaving land uncultivated due to salinity is the significant cause of spread of salinity in the area. The results will be helpful in designing mitigation strategies against salinity by the policy makers/ planners.

\section{Author's Contribution}

Arshad Mahmood Malik: Wrote abstract, conclusion, technical input at every step, overall management of the article, result and discussion, references.

Hafiz Muhammad Tayyab: Conceived the idea, wrote abstract, methodology, did SPSS analysis, conclusion, data collection, data entry in SPSS and analysis, result and discussion, introduction, references.

Muhammad Arshad Ullah: Technical input at every step, overall management of the article, introduction, references.

Muhammad Talha Bilal: Did SPSS analysis, conclusion, technical input at every step, overall management of the article, references.

\section{Conflict of interest}

The authors have declared no conflict of interes.

\section{References}

Acosta, J.A., A. Faz, B. Jansen, K. Kalbitz and S. Martínez-Martínez. 2011. Assessment of salinity status in intensively cultivated soils under semiarid climate, Murcia, SE Spain. J. Arid Environ., 75(11): 1056-1066. https://doi. org/10.1016/j.jaridenv.2011.05.006

Aldesuquy, H.S. and A.H. Ibrahim. 2002. Water relations-abscisic acid and yield of wheat plants in relation to the interactive effect of seawater and growth bioregulators [Triticumaestivum L.]. Agrochimica (Italy).

Ashraf, M., 2009. Biotechnological approach of improving plant salt tolerance using 
antioxidants as markers. Biotechnol. Adv., 27(1): 84-93. https://doi.org/10.1016/j. biotechadv.2008.09.003

Atlassi, P.V., M. Nabipour and M. Meskarbashee. 2009. Effect of salt stress on chlorophyll content, Fluorescence, $\mathrm{Na}+$ and $\mathrm{K}+$ ions content in Rape plants (Brassica napus L.). Asian J. Agric. Res., 3(2): 28-37. https://doi.org/10.3923/ ajar.2009.28.37

Baath,G.S.,M.K.Shukla,P.W.Bosland,R.L.Steiner and S.J. Walker. 2017. Irrigation water salinity influences at various growth stages of Capsicum annuum. Agric. Water Manage., 179: 246-253. https://doi.org/10.1016/j.agwat.2016.05.028

Bureau of Statistics Punjab, 2020. Punjab Development Statistics 2003 and 2019, Bureau of Statistics Government of The Punjab Lahore.

Chopra, R.P.S., and G. Krishan. 2014. Assessment of groundwater quality in Punjab, India. J. Earth Sci., Clim. Change, 5(3): 1-3.

Das, P., 2019. Linear regression model: Goodness of fit and testing of hypothesis. In: Econometrics in theory and practice. Springer, Singapore. https://doi.org/10.1007/978-98132-9019-8 3

E1-Hendawy, S.E., Y. Hu, G.M. Yakout, A.M. Awad, S.E. Hafiz and U. Schmidhalter. 2005. Evaluating salt tolerance of wheat genotypes using multiple parameters. Eur.J. Agron., 22(3): 243-253. https://doi.org/10.1016/j. eja.2004.03.002

FAO, 2010. FAO Land and plant nutrition management service.

Foster, S., A. Pulido-Bosch, A. Vallejos, L. Molina, A. Llop and A.M. MacDonald. 2018. Impact of irrigated agriculture on groundwater-recharge salinity: A major sustainability concern in semiarid regions. Hydrogeol. J., 26(8): 2781-2791. https://doi.org/10.1007/s10040-018-1830-2

Gao, X., Z. Huo, Y. Bai, S. Feng, G. Huang, H. Shi and Z. Qu. 2015. Soil salt and groundwater change in flood irrigation field and uncultivated land: A case study based on 4-year field observations. Environ. Earth Sci., 73(5): 21272139. https://doi.org/10.1007/s12665-0143563-4

Ghane, E., B. Mostafazadeh-Fard, M. Feizi and E. Landi.2011.Effect of water quality and different planting methods on wheat yield. Commun. Soil Sci. Plant Anal., 42(4): 369-380. https:// doi.org/10.1080/00103624.2011.542225
GOP, 1981. Pakistan census of agriculture 1980. Lahore: Ministry of food and agriculture, agriculture census organisation, Government of Pakistan.

GOP, 1991. Pakistan census of Agriculture 1990. Lahore: Ministry of food and agriculture, agriculture census organisation Government of Pakistan.

GOP, 2001. Pakistan census of agriculture 2000. Lahore: Ministry of food and agriculture, agriculture census organization Government of Pakistan.

GOP, 2011. Pakistan census of Agriculture 2010. Lahore: Ministry of food and agriculture, agriculture census organisation Government of Pakistan.

GOP, 2012. Agricultural statistics of Pakistan.

GOP,2020. Economic survey of Pakistan, economic advisor's wing, ministry of finance, Government of Pakistan.

Gujarati, D.N. and D.C. Porter. 2003. Basic Econometrics (ed.). New York: McGraw-HiII.

Heidarpour, M., B. Mostafazadeh-Fard, A. Arzani, A. Aghakhani and M. Feizi. 2009. Effects of irrigation water salinity and leaching fraction on yield and evapotranspiration in spring wheat. Commun. Soil Sci. Plant Anal., 40(15-16): 2521-2535. https://doi. org/10.1080/00103620903111384

Hillel, D., 2000. Salinity management for sustainable irrigation: integrating science, environment, and economics. The World Bank. https://doi.org/10.1596/0-8213-4773-X

Hollington, P.A., 1998. Technological breakthroughs in screening/ breeding wheat varieties for salt tolerance. Proceedings of the national conference on salinity management in agriculture. Karnal, India: CSSPI. pp. 2-5.

Hussain, Y., A. Ullah, G. Akhter and A.Q. Aslam. 2017. Groundwater quality evaluation by electrical resistivity method for optimized tubewell site selection in an ago-stressed Thal Doab Aquifer in Pakistan. Model. Earth Syst. Environ. 3(1): 15. https://doi.org/10.1007/ s40808-017-0282-3

Inam, A., J. Adamowski, S. Prasher, J. Halbe, J. Malard and R. Albano. 2017. Coupling of a distributed stakeholder-built system dynamics socio-economic model with SAHYSMOD for sustainable soil salinity management. Part 2: Model coupling and 
application. J. Hydrol., 551: 278-299. https:// doi.org/10.1016/j.jhydrol.2017.03.040

Khan, A.N., S. Ullah, S. Gul and S. Mahmood. 2016. Impacts evaluation of chashma right bank canal on the water table of District Dera Ismail Khan, Pakistan. J. Basic Appl. Sci., 12: 281-288. https://doi.org/10.6000/19275129.2016.12.43

Khan, M. and W. Khan. 2020. Socioeconomic and recharge effect on spatial changes in the groundwater chemistry of Punjab, Pakistan: A multivariate statistical approach. SN Appl. Sci., 2: 1465. https://doi.org/10.1007/s42452020-03255-3

Mojid, M.A., S.K. Biswas and G.C.L. Wyseure. 2012. Interaction effects of irrigation by municipal wastewater and inorganic fertilizers on wheat cultivation in Bangladesh. Field Crops Res., 134: 200-207. https://doi.org/10.1016/j. fcr.2012.06.010

Mustafa, G. and M.S. Akhtar. 2019. Crops and methods to control soil salinity. In: Akhtar M. (eds) Salt stress, microbes, and plant interactions: Mechanisms and molecular approaches. Springer, Singapore. https://doi. org/10.1007/978-981-13-8805-7_11

Mutl, J. and M. Pfaffermayr. 2011. The hausman test in a cliff and Ord panel model. Econ. J., 14(1): 48-76. https://doi.org/10.1111/ j.1368-423X.2010.00325.x

Rodrigues, M.S., D.C. Alves, J.C. Cunha, A.M.N. Lima, I.H.L. Cavalcante, K.A. da Silva and J.C.F. de Melo-Junior. 2018. Spatial analysis of soil salinity in a mango irrigated area in semiarid climate region. Aust. J. Crop Sci., 12(8): 1288.

Sagin, J., D. Adenova, A. Tolepbayeva and V. Poryadin. 2017. Underground water resources in Kazakhstan. Int. J. Environ. Stud., 74(3): 386-398. https://doi.org/10.1080/00207233.2 017.1288059

Shannon,M.C. and C.M.Grieve.1998.Tolerance of vegetable crops to salinity. Scientiahorticulturae, 78(1-4): 5-38. https://doi.org/10.1016/S0304-
4238(98)00189-7

Sheikhzeinoddin, A., A. Esmaeili and M. Zibaei. 2016. Management of water and fertilizer consumption using bio-economic approach: A case study of irrigation and drainage dorudzan. Agric. Econ. Dev., 24(93): 27-47.

Tilman, D., K.G. Cassman, P.A. Matson, R. Naylor and S. Polasky. 2002. Agricultural sustainability and intensive production practices. Nature, 418(6898): 671-677. https:// doi.org/10.1038/nature01014

USDA, 2011. Pakistan: Crop progress report, FAS Office of Global Analysis (OGA) United States Department of Agriculture (USDA) International Operational Agriculture Monitoring Program

Valipour, M., 2014. Drainage, waterlogging, and salinity. Arch. Agron. Soil Sci., 60(12): 16251640. https://doi.org/10.1080/03650340.2014. 905676

Williams, W.D., 2001. Anthropogenic salinisation of inland waters. In Saline lakes. Springer, Dordrecht. pp. 329-337. https://doi. org/10.1007/978-94-017-2934-5_30

World Bank, 2015. World Bank Annual Report, 2015. Washington, D.C.

Yadav, S., M. Irfan, A. Ahmad and S. Hayat. 2011. Causes of salinity and plant manifestations to salt stress: A review. J. Environ. Biol., 32(5): 667.

Yokoi, S., F.J. Quintero, B. Cubero, M.T. Ruiz, R.A. Bressan, P.M. Hasegawa and J.M. Pardo. 2002. Differential expression and function of Arabidopsis thaliana $\mathrm{NHX} \mathrm{Na}+\mathrm{H}+$ antiporters in the salt stress response. Plant J., 30(5): 529-539. https://doi.org/10.1046/j.1365313X.2002.01309.x

Zeng, Y., 2019. Classical linear regression model: Assumptions and diagnostics test.

Zinck, A., 2002. Monitoring soil salinity from remote sensing data. Deposits and Geoenvironmental Models for resources exploitation and environmental security II, pp. 28. 